\title{
The possible protective role of 6-gingerol on a model of hepatic injury induced by carbon tetrachloride in adult male albino rats: Histological and immunohistochemical study
}

\section{Original Article}

\author{
Hany K. K. Mostafa, Ghada Galal Hamam and Dalia Alaa El-Din Aly El-Waseef \\ Department of Histology \& Cell Biology, Faculty of Medicine, Ain Shams University, Cairo, \\ Egypt
}

\begin{abstract}
Introduction: Carbon tetrachloride $\left(\mathrm{CCL}_{4}\right)$ is a potent environmental hepatotoxin that was commonly used in industrial applications. The main active component in ginger is 6-gingerol which is responsible for many of its medicinal properties.

Aim of the work: To assess the possible protective role of orally administered 6-gingerol on a model of hepatic injury induced by $\mathrm{CCL}_{4}$ in adult male albino rats.

Materials and Methods: Thirty adult male albino rats were used in this study and were divided into three groups. Group I: control group which was further subdivided into three subgroups, group II: received intraperitoneal injection of $\mathrm{CCL}_{4}$ twice / week for two weeks. Group III: received oral 6-gingerol daily five days before the injection of $\mathrm{CCL}_{4}$-as in group II- and continued till the end of experiment. After two weeks from last injection of $\mathrm{CCL}_{4}$. All rats were sacrificed; the right lobe of the liver was taken and processed. Sections stained by H\&E, Mallory`s trichrome stain and immunostaining for TNF- $\alpha$ and PCNA were prepared. Morphometric and statistical analysis were also performed.

Results: Liver of group II showed hepatocytes with vacuolated cytoplasm and congested hepatic sinusoids. Congested portal veins and dilated bile ducts were also seen at portal tract areas. Increased collagen fibers at the portal tract areas were seen by Mallory's trichrome. Increased intensity of positive immune reaction for TNF- $\alpha$ and PCNA was also observed in this group. In group III the liver showed picture nearly similar to that of the control. Morphometric and statistical analysis confirmed the histological and immunohistochemical results.

Conclusions: The present work concluded that 6-gingerol could provide a good protection of the liver in a model of hepatic injury induced by $\mathrm{CCL}_{4}$.
\end{abstract}

Key Words: Carbon tetrachloride, gingerol, hepatocytes, histology, PCNA, TNF- $\alpha$

Revised: 20 September 2017, Accepted: 29 September 2017

Corresponding Author: Ghada Galal Hamam, Department of Histology \& Cell Biology, Faculty of Medicine, Ain Shams University, Cairo, Egypt, Tel.: 0201003960601, E-mail: ghada.hamam@yahoo.com

ISSN: 1110-0559, September Vol. 40, No. 3

\section{INTRODUCTION}

Liver is the key organ in metabolism, detoxification, and secretory functions in the body ${ }^{[1]}$. Liver dysfunction has increased for the past few decades due to increased exposure to toxic chemicals, various drugs and to environmental pollutants ${ }^{[2]}$. The liver deals with most of the chemicals entering the body so, it is at high risk of damage. Hepatocytes are the main functional cells of the liver and constitute $60 \sim 80 \%$ of the mass of the liver tissue ${ }^{[3]}$.

Carbon tetrachloride $\left(\mathrm{CCL}_{4}\right)$ is a potent environmental hepatotoxin that was earlier commonly used in industrial applications ${ }^{[4]}$. Occupational exposure to $\mathrm{CCL}_{4}$ may occur in the chemical industry, in laboratories, and during degreasing operations, through inhalation, ingestion, or dermal contact ${ }^{[5]}$.

Herbal medicines are increasingly used worldwide with increased use of complementary and alternative therapies by patients with liver disease ${ }^{[6]}$. Between $20 \%$ and $65 \%$ of patients in West use complementary and alternative Medicine on regular basis ${ }^{[7]}$. Ginger (underground rhizomes of Zingiber officinale) is a famous spice which was used for centuries as a medicinal plant in different traditional medicine ${ }^{[8]}$. Ginger is widely used especially in Asia, and it contains several bioactive constituents and possesses health promoting properties ${ }^{[9]}$. The main active component in ginger is 6-gingerol which is responsible for many of its medicinal properties. It is also responsible for its distinctive flavor ${ }^{[10]}$. Gingerol is very effective in alleviating symptoms of gastrointestinal illness. For centuries, it was an important ingredient in herbal medicine in treatment of rheumatism, gingivitis, toothache, asthma, stroke, vomiting and diabetes ${ }^{[11]}$.

Tumor necrotizing factor alpha (TNF- $\alpha$ ) is a proinflammatory cytokine. It is produced by inflammatory cells like monocytes, macrophages, and neutrophils. It stimulates cytokine secretion and augments the inflammatory response in $\operatorname{turn}^{[12]}$. 
Proliferating cell nuclear antigen (PCNA) known also as cyclin, is a non-histone nuclear protein whose level of synthesis correlates directly with rates of cellular proliferation and DNA repair and synthesis ${ }^{[13]}$.

\section{AIM OF THE WORK}

In the present study, we shed a focus on the possible protective role of 6-gingerol in hepatic injury induced by CCL4 in adult male albino rats.

\section{MATERIALS AND METHODS}

\section{Animals and diet}

Thirty adult male albino rats weighing 180-200 gm were purchased from the Medical Research Center in Ain Shams University. The rats were housed in wire mesh cages under standard experimental conditions. They had free access to water and a standard diet. Animals were kept for one week before the beginning of the experiment for acclimatization. All animal procedures were carried out according to the guidelines of animal care and the ethical committee of the faculty of Medicine, Ain Shams University.

\section{Drugs and chemicals}

Carbon tetrachloride is a colorless liquid. It was obtained from Al-Gomhoria Cooperation (Cairo, Egypt) in a $100 \%$ concentration. It was dissolved in olive oil at a dilution of 1:1 ratio.

Tween $80(0.5 \%)$ was purchased from Sigma Chemical Co. (St. Louis, MO, USA). All other chemicals and solvents were of highest grade and commercially available.

Six gingerol was isolated and prepared from Zingiber officinale $^{[14]}$ in the Department of Pharmacology and Therapeutics Faculty of Medicine Ain Shams University. Five drops of $0.5 \%$ tween 80 were put on one gram of 6-gingerol then it was dissolved in one liter distilled water, so that one $\mathrm{ml}$ distilled water has $1 \mathrm{mg} 6$-gingerol.

\section{Experimental protocol:}

\section{Animals were randomly divided into three groups:}

Group I: (Control group): This group comprised 18 rats that were further subdivided into three subgroups six rats each:

Subgroup Ia: served as untreated control group.

Subgroup $\mathrm{Ib}$ : received $1 \mathrm{ml}$ of $0.5 \%$ tween 80 in distilled water daily by gastric gavage from the first day till the end of experiment. At day five they received IP injection of $1 \mathrm{ml} / \mathrm{Kg}$ olive oil twice weekly for two weeks. Olive oil was the solvent for $\mathrm{CCL}_{4}$ while tween 80 was the solvent of 6-gingerol.
Subgroup Ic: (6-gingerol group): received 6-gingerol by gastric gavage at a dose of $10 \mathrm{mg} / \mathrm{kg}$ daily from the first day till the end of experiment ${ }^{[15]}$.

Group II: ( $\mathrm{CCL}_{4}$ group): included six rats that received IP injections of $\mathrm{CCL}_{4}(1 \mathrm{ml} / \mathrm{kg}$ body weight, dissolved 1:1 in olive oil) twice weekly for two weeks ${ }^{[16]}$.

Group III: (6-gingerol pre-treated group): included six rats that were pretreated with 6-gingerol. It was given daily to rats by gastric gavage at a dose of $10 \mathrm{mg} / \mathrm{kg}$ starting five days ${ }^{[15]}$ before the IP injection of $\mathrm{CCL}_{4}$ as in group II and continued till the end of experiment.

\section{Sample Collection:}

After the last injection with $\mathrm{CCL}_{4}$, a period of two weeks was permitted then all rats were sacrificed after overnight fasting (12 hours).

At the end of the experiment, all rats were sacrificed by cervical dislocation under thiopental sodium phosphate at a dose of $40 \mathrm{mg} / \mathrm{kg}$ body weight intraperitoneally calculated according to Paget and Barnes equation ${ }^{[17]}$. The liver was dissected through an abdominal incision. The right lobe from each specimen was processed for the following studies.

\section{Histological and immunohistochemical studies ${ }^{[18]}$}

Preparation of paraffin sections

Each specimen was fixed in $10 \%$ formol saline, dehydrated, cleared, and paraffin sections were prepared as usual and were subjected to staining with the following:

(I) Histological stains:

H\&E. and Mallory's trichrome stain.

(II) Immunohistochemical stains:

Avidin-biotin immunohistochemical staining for TNF- $\alpha$ and PCNA.

\section{Immunohistochmeical techniques:}

The kit of TNF- $\alpha$ was supplied from R\&D Systems (Minneapolis, Minnesota, USA). Catalog number \# MAB510R. The kit for PCNA was supplied by Santa Cruz biotechnology Dallas Texas USA Catalog number: PCNA Antibody (F-2): sc-25280.

Avidin-biotin peroxidase immunohistochemical staining technique

Paraffin sections were put on positively charged glass slides. Then sections were deparaffinized, hydrated, and 
then put in $10 \% \mathrm{H}_{2} \mathrm{O}_{2}$ to block endogenous peroxidase activity. Unmasking of antigenic sites was carried out by transferring the sections into a jar containing $0.001 \mathrm{M}$ citrate buffer $(\mathrm{pH} 6)$ and then boiling in a microwave for four minutes at temperature grade VIII, followed by two minutes at grade II. Incubation with 1/100 normal rabbit serum for 20 minutes was carried out to block nonspecific background staining. The diluted goat anti rat primary antibody was then added on the slides and kept for two hours. The slides were then washed with phosphate buffer saline (PBS), and 1/400 biotinylated rabbit antigoat IgG secondary antibody was then added to the slides and kept for one hour. Streptavidin peroxidase was then added to bind with biotin residue on the linking antibody for 10 minutes, and then washed with PBS. The site of antibody immunostaining was visualized using the avidin-biotin peroxidase complex (ABC reagent) for 30 minutes. Freshly prepared diaminobenzidine was used as chromogen. The sections were incubated with diaminobenzidine for 10 minutes and then washed with tap water, dehydrated, and mounted. For negative control, the primary antibody was replaced with PBS. Haematoxylin was used as counter stain.

\section{Results for TNF- $\alpha$ immunohistochmeical technique:}

(1) TNF- $\alpha$ was seen as brown cytoplasmic reaction.

(2) No reaction for TNF- $\alpha$ was detected in negative control run.

(3) Positive control was supplied by santa cruz biotechnology as an image for inflamed dermis of the skin.

\section{Results for PCNA immunohistochmeical technique:}

(1) Positive nuclear reaction appeared brown.

(2) No reaction for PCNA was detected in negative control run.

(3) Positive control was supplied by santa cruz biotechnology as an image for keratinocytes of epidermis of the skin.

\section{Morphometric and statistical study:}

An image analyzer Leica Q win V.3 program installed on a computer in the Department of Histology and cell biology, Faculty of Medicine, Ain Shams University, was used. The computer was connected to a Leica DM2500 microscope (Wetzlar, Germany). Five different non overlapping fields from five different sections of different rats were examined in each group $(\mathrm{N}=6)$ for measuring each of the following:

1. Mean area percentage of collagen fibers stained by Mallory's trichrome.
2. Mean area percentage for positive immune reaction of TNF- $\alpha$.

3. Mean area percentage for positive immune reaction of PCNA.

4. Mean number of nuclei with positive immune reaction of PCNA.

All measurements were taken at medium-power fields of magnification objective lens (x20).

All values were presented as mean \pm standard deviation (SD). All data were collected, revised, and subjected to statistical analysis using one-way analysis of variance performed using SPSS.21 program (IBM Inc., Chicago, Illinois, USA). The calculations were considered significant if $P<0.05^{[19]}$.

\section{RESULTS}

\section{General appearance:}

Carbon tetrachloride-treated rats were obviously ill and unable to move readily, with fur raised, scruffy coupled with apparent weight loss and decreased food intake. These rats also had red exudates around the nose and eyes, soft stool and enlargement of abdomen. Rats exposed to ginger alone appeared healthy in all aspects. All rats in the ginger plus $\mathrm{CCL}_{4}$ combination treatment group appeared healthy with minimal signs and symptoms of illness.

\section{Histological results:}

Examination of H\&E stained sections of control group (subgroups $\mathrm{Ia}, \mathrm{Ib}$ and Ic) showed the same findings. They revealed the usual appearance of liver sections. The parenchyma of the liver showed branching and anastomosing cords of liver cells with central vein at the center and portal tract areas at the periphery (Fig. 1). Hepatic sinusoids were seen in between the cords of hepatocytes. The sinusoids were lined by flat endothelial cells. The hepatocytes were seen polygonal in shape with acidophilic cytoplasm containing basophilic granules and central vesicular rounded nuclei. Some hepatocytes contained two nuclei (Fig. 2). The portal tract areas showed branches of portal vein, hepatic artery, bile duct and lymphatic vessels. These structures were supported by minimal connective tissue (Fig. 3). In rats treated with $\mathrm{CCL}_{4}$, examination of $\mathrm{H} \& \mathrm{E}$ stained sections showed disturbed radial arrangement of the hepatocytes. Hepatocytes showed vacuolated cytoplasm (Figs. 4 \& 5). Hepatic sinusoids were seen obliterated in some sections (Fig.5) and appeared congested in others. Central veins were also seen congested (Fig. 6). At portal tract areas, mononuclear cellular infiltration was frequently noticed (Fig. 7) and bile ducts were seen dilated (Figs: 7 \& 8). 
Proliferation of bile ducts was also frequently seen at the periphery of hepatic lobules (Fig. 8).

In rats given 6-gingerol with $\mathrm{CCL}_{4}$, examination of $H \& E$ stained sections showed hepatocytes arranged in branching and anastomosing cords with acidophilic cytoplasm vesicular nuclei and some were binucleated. Few hepatocytes had vacuolated cytoplasm (Fig. 9). The portal tract areas showed picture similar to that of the control group. Moderate branching of bile ducts were seen at portal tract (Fig. 10).

In Mallory's trichrome stained sections of the control group, the apparent few bluish stained collagen fibers were seen around the central vein and at portal tract areas (Fig. 11). While in $\mathrm{CCL}_{4}$ treated rats, there was an apparent increase in the collagen fibers at the portal tract areas and around central veins (Fig. 12). In rats given 6-gingerol with $\mathrm{CCL}_{4}$, an apparent decrease in the collagen fibers especially at the portal tract areas was noticed in comparison to the group II (Fig. 13).

In the control group, negative immune reaction for TNF- $\alpha$ was noticed (Fig. 14). While, in $\mathrm{CCL}_{4}$ treated rats, apparently dense immune reaction for TNF- $\alpha$ was noticed in cytoplasm of hepatocytes (Fig. 15), and in rats given 6-gingerol with $\mathrm{CCL}_{4}$, negative immune reaction was noticed in the cytoplasm of hepatocytes (Fig. 16).
In the control group, few faint PCNA positive nuclei were seen in the hepatocytes (Fig. 17). In $\mathrm{CCL}_{4}$ group, most of hepatocytes had nuclei with intense positive PCNA immune reaction (Fig. 18). Positive immune reaction for PCNA was also noticed at the portal tract areas in nuclei of cells lining proliferating bile ducts (Fig. 19). While in rats given 6-gingerol with $\mathrm{CCL}_{4}$, an apparent reduction in the number of PCNA positive nuclei were noticed compared with sections from rats of group II (Fig. 20).

\section{Morphometric and statistical results:}

There was a significant increase in the mean area percentage of collagen fibers, and the mean area percentage of TNF- $\alpha$ and PCNA positive immune reaction, in group II compared to subgroups Ia, Ib, Ic and group III. Non significant changes were noticed in group III in all measured parameters compared to subgroups $\mathrm{Ia}, \mathrm{Ib}$ and Ic, while a significant decrease was noticed compared to group II (table 1, histogram 1).

There was a significant increase in the mean number of PCNA positive nuclei in group II compared to subgroups Ia, Ib, Ic and group III. Non significant change was noticed in group III compared to subgroups Ia, Ib and Ic, while a significant decrease was noticed compared to group II (table 1, histogram 2).

Table 1: showing the comparison between different groups as regard mean area percentage of collagen fibers, TNF- $\alpha$ and PCNA immune reaction and the mean number of PCNA positive nuclei:

\begin{tabular}{lcccc}
\hline & $\begin{array}{c}\text { Mean area percentage } \\
\text { of collagen fibers }\end{array}$ & $\begin{array}{c}\text { Mean area percentage } \\
\text { of TNF- } \alpha\end{array}$ & $\begin{array}{c}\text { Mean area percentage } \\
\text { of PCNA }\end{array}$ & $\begin{array}{c}\text { Mean number of PCNA } \\
\text { positive nuclei }\end{array}$ \\
\hline Subgroup Ia & $5.917 \pm 0.76$ & $0.783 \pm 0.37$ & $2.91 \pm 0.584$ & $54 \pm 1.5$ \\
Subgroup Ib & $6.017 \pm 0.682$ & $0.750 \pm 0.359$ & $2.867 \pm 0.562$ & $55.5 \pm 2.36$ \\
Subgroup Ic & $5.967 \pm 0.66$ & $0.583 \pm 0.450$ & $2.88 \pm 0.406$ & $55 \pm 2.16$ \\
Group II & $17.3 \pm 0.825^{*}$ & $23.833 \pm 2.115^{*}$ & $7.08 \pm 0.669^{*}$ & $133 \pm 6.7^{*}$ \\
Group III & $6 \pm 0.816 \#$ & $2.2 \pm 0.554 \#$ & $3.31 \pm 0.234 \#$ & $68.8 \pm 2.5 \#$ \\
\hline
\end{tabular}

* Significant change in comparison to other groups $\mathrm{P}<0.05$

\# Non significant change in comparison to subgroups Ia, Ib and Ic P $>0.05$

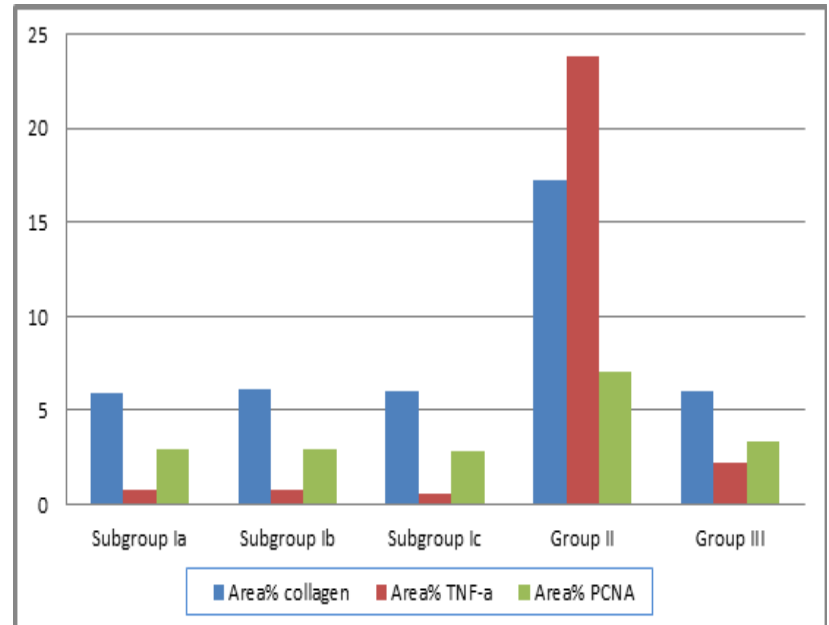

Histogram 1: showing the mean area percentage of collagen fibers, TNF- $\alpha$ and PCNA immune reaction in different groups (medium power $\mathrm{x} 20$ ):

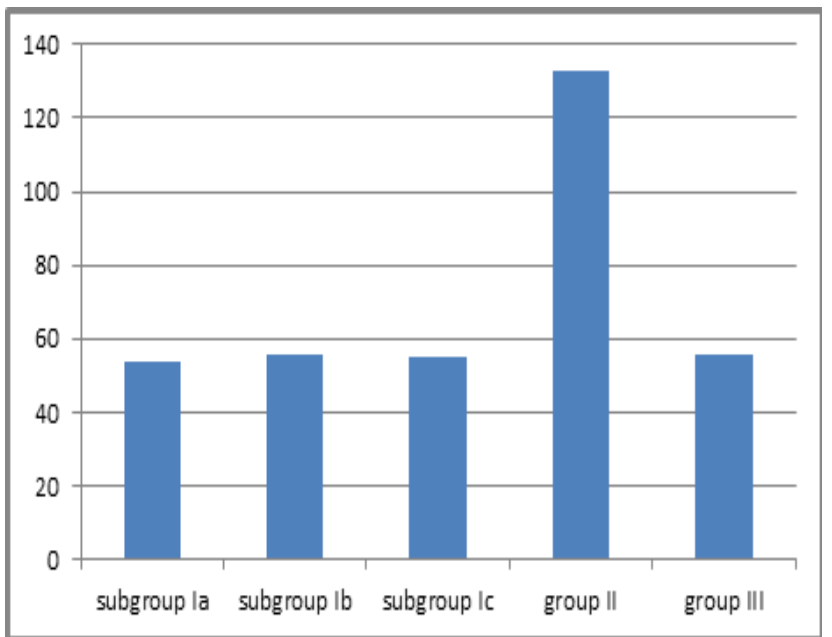

Histogram 2: showing the mean number of cells showed positive immune reaction to PCNA in different groups (medium power $\mathrm{x} 20)$ : 


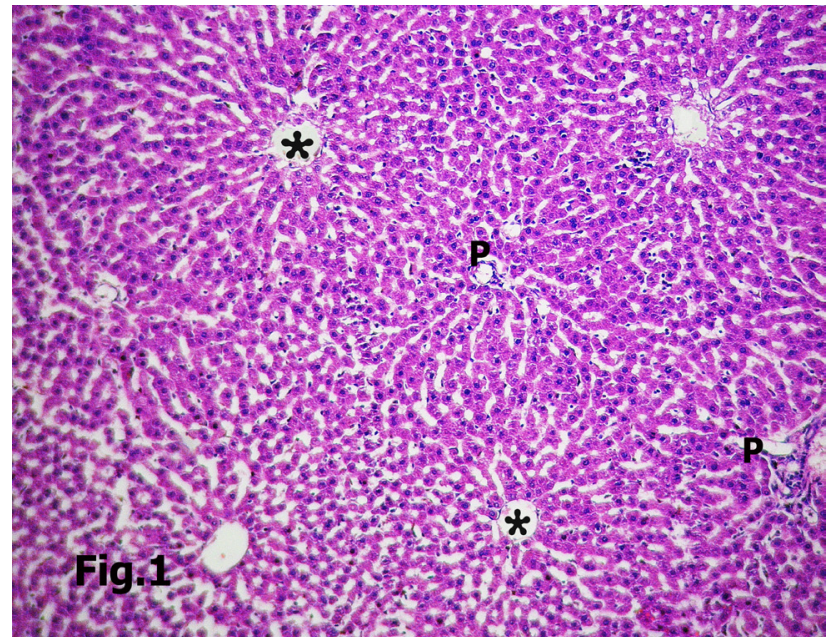

Fig. 1: showing the general appearance of the classic hepatic lobules which are seen traversed by central vein $(*)$ and peripherally situated portal tracts (P). Subgroup Ia (H\&E X 100).

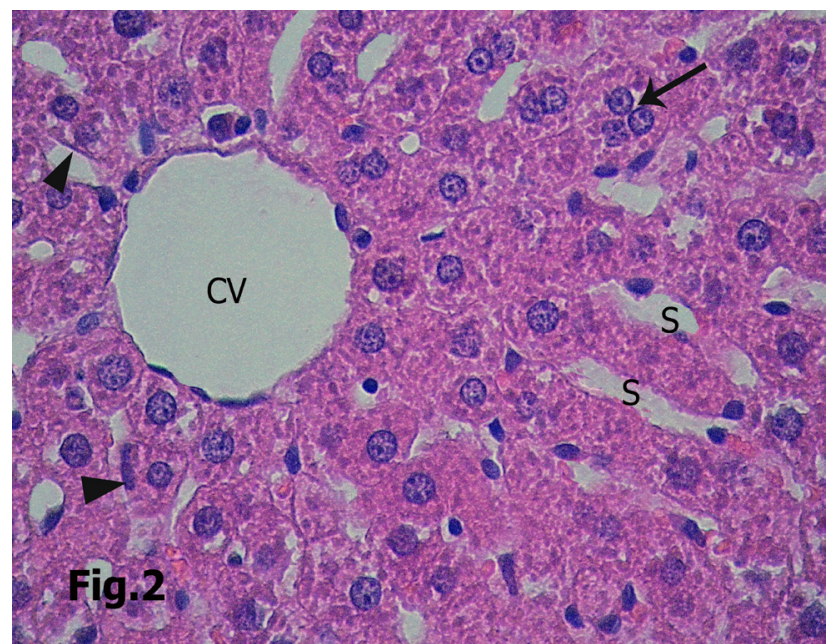

Fig. 2: Cords of hepatocytes are seen radiating from the centrally loc.ated central vein $(\mathrm{CV})$. These cords are arranged in branching and anastomosing pattern. Hepatocytes appear polygonal in shape with acidophilic cytoplasm containing basophilic granules and central, rounded, vesicular nuclei. Binucleated cells $(\uparrow)$ are also seen. In-between the hepatic cords, blood sinusoids (S) are seen as slit like spaces lined by flat endothelial cells $(\boldsymbol{\Lambda})$.

Subgroup Ib (H\&E X 640).

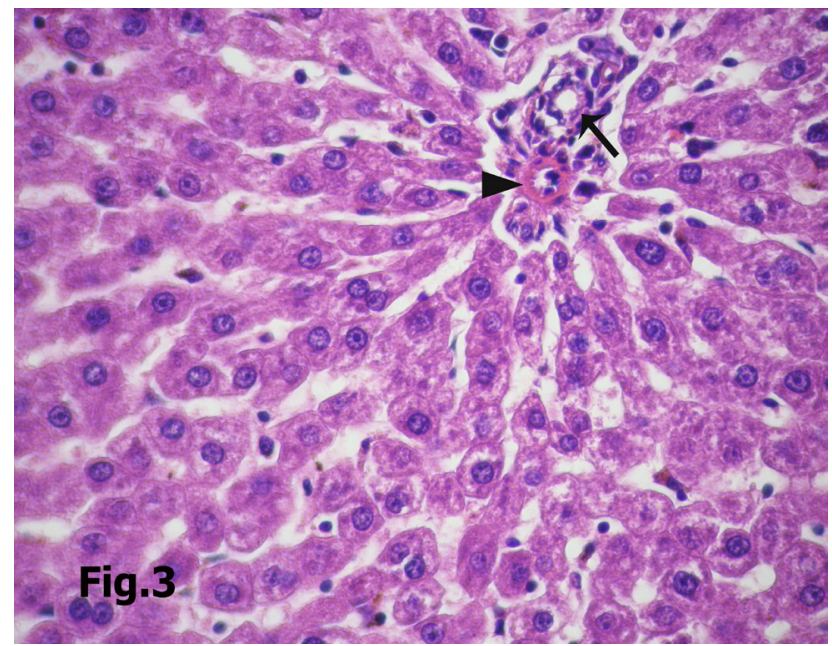

Fig. 3: showing the portal area and the surrounding hepatocytes. The portal area contains a branch from the hepatic artery $(\boldsymbol{\Delta})$, and a bile duct ( $\uparrow)$
Subgroup Ic (H\&E X 640).

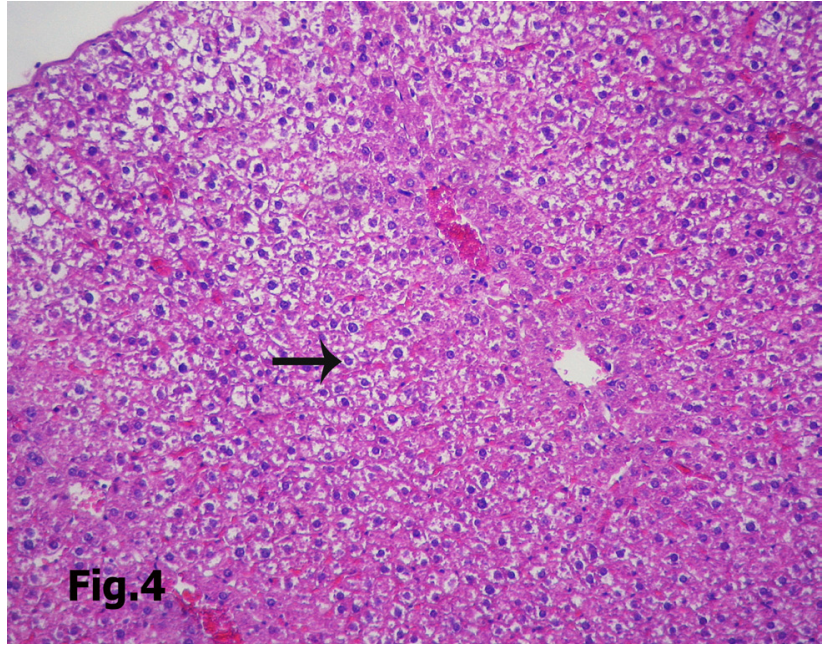

Fig. 4: showing most of hepatocytes with vacuolated cytoplasm $(\uparrow)$. Group II (H\&E X100).

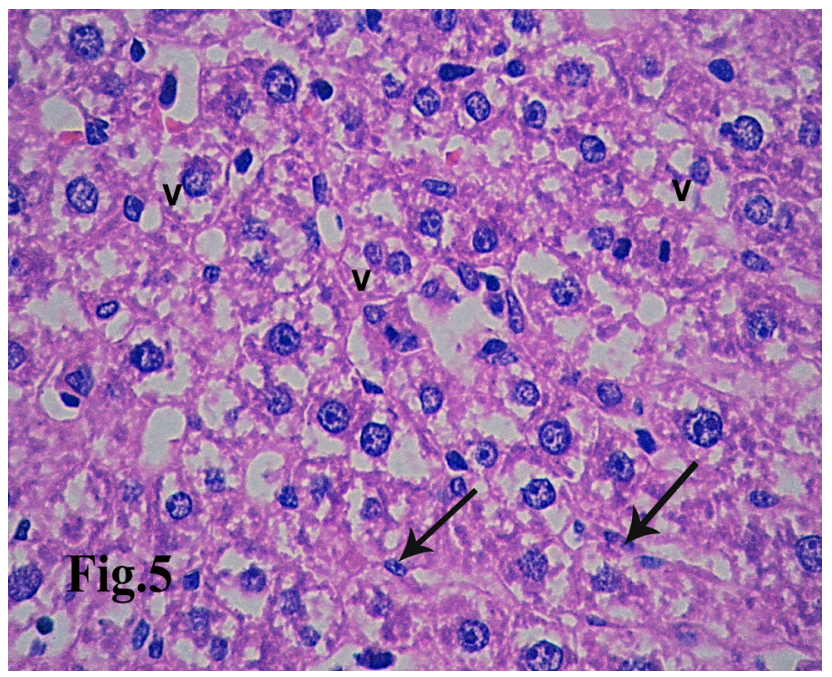

Fig. 5: showing disturbed radial arrangement of hepatic cords. Vacuolated hepatocytes are seen (V). Notice obliterated blood sinusoids $(\uparrow)$.

Group II (H\&E X640).

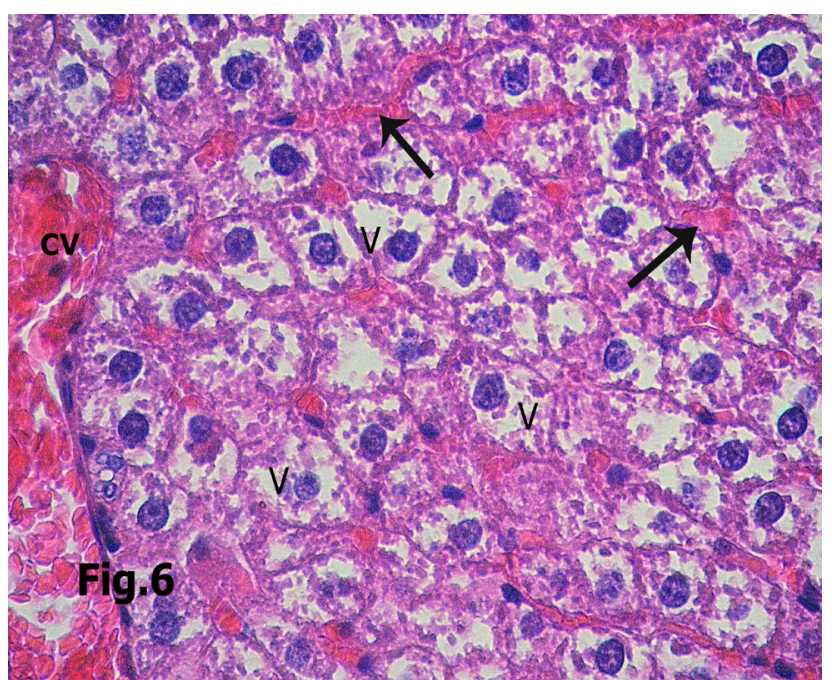

Fig. 6: showing dilated congested central vein (CV). Hepatocytes are seen with extensive vacuolated cytoplasm (V). Blood sinusoids $(\uparrow)$ are seen congested. $\quad$ Group II (H\&E X640). 


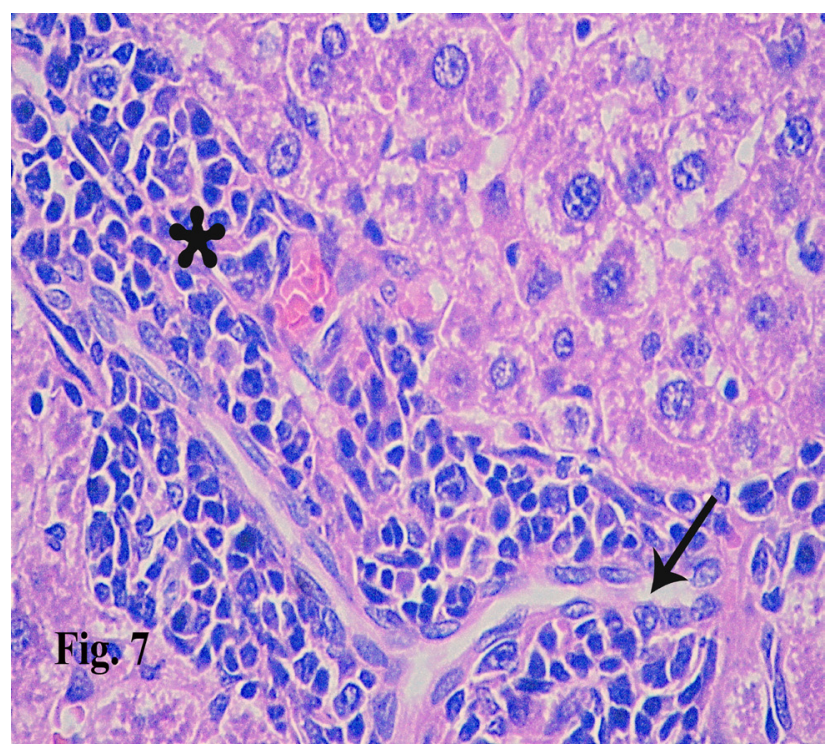

Fig. 7: showing cellular infiltration in the portal tract $(*)$ and dilated bile duct $(\uparrow)$. Group II (H\&E X640).

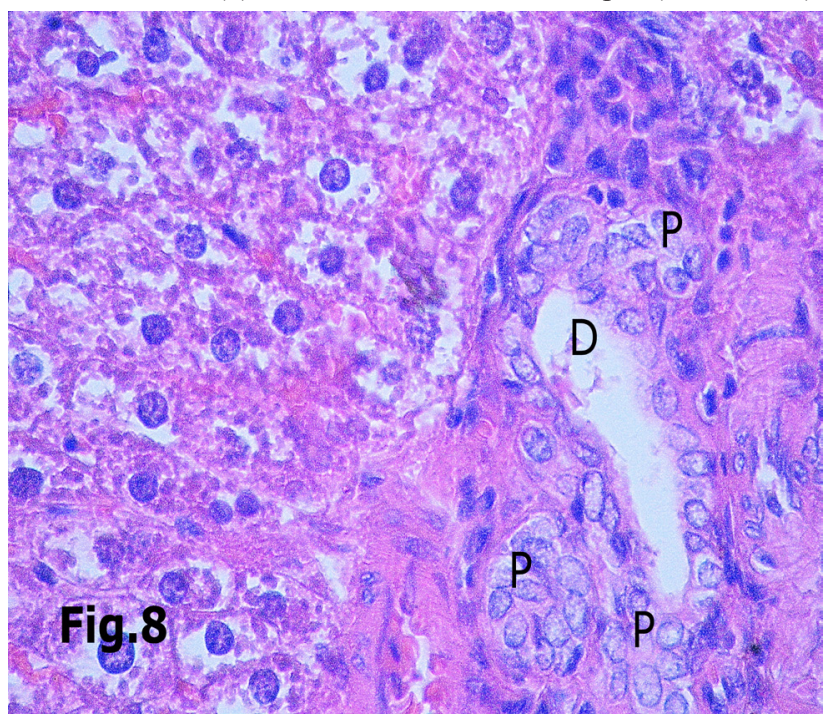

Fig. 8: showing dilatation (D) and proliferation (P) of bile ducts in the portal tract area. Group II (H\&E X640).

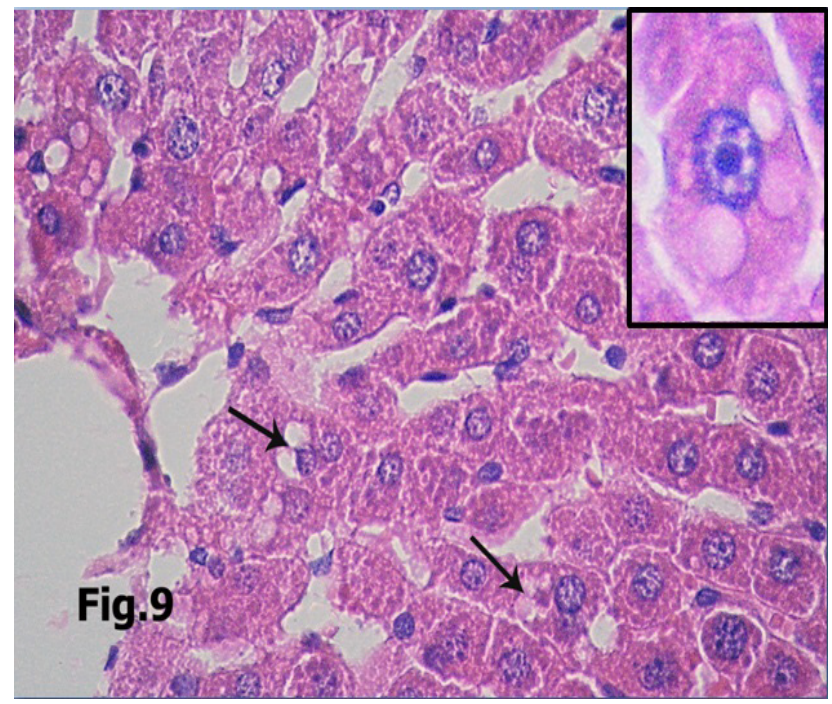

Fig. 9: showing few hepatocytes with vacuolated cytoplasm ( $\uparrow$ ). Group III (H\&E X640) Inset X1000.

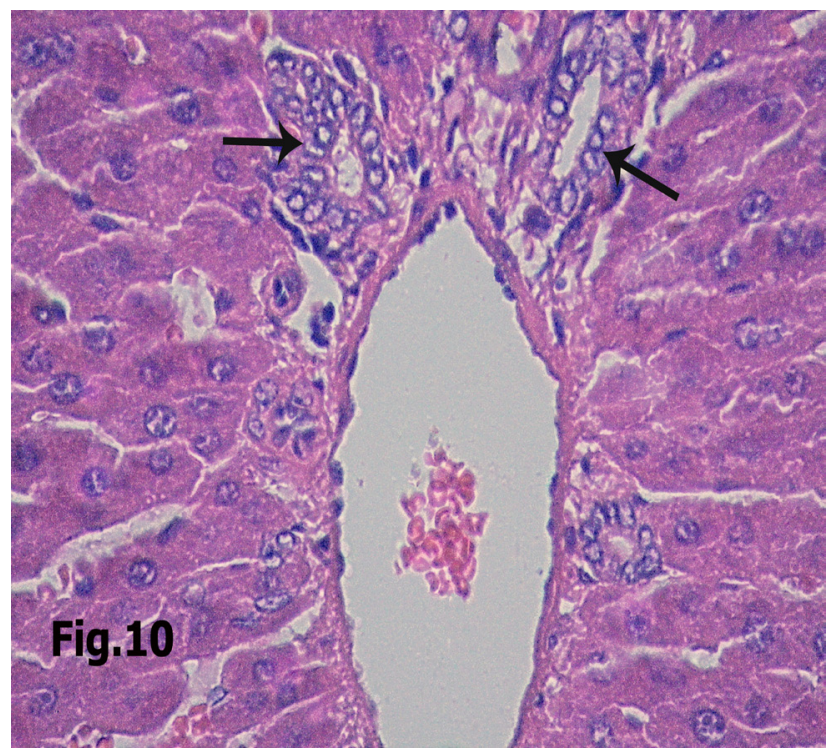

Fig. 10: showing moderate branching of bile ducts $(\uparrow)$ in the portal tract area.

Group III (H\&E X640)
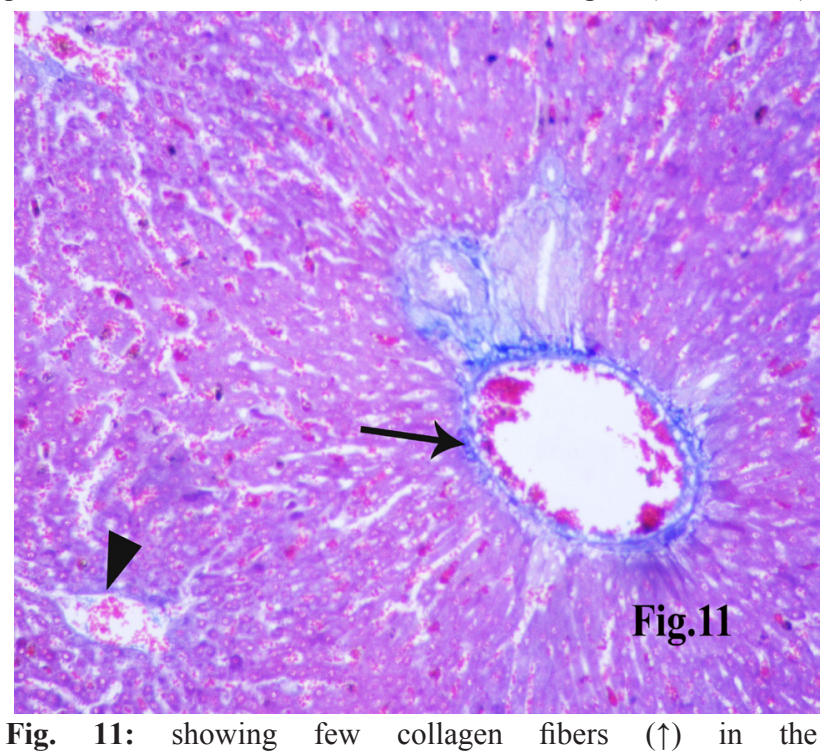

portal tract and around the central vein $(\boldsymbol{\Delta})$

Group Ia (Mallory's triple stain X250)

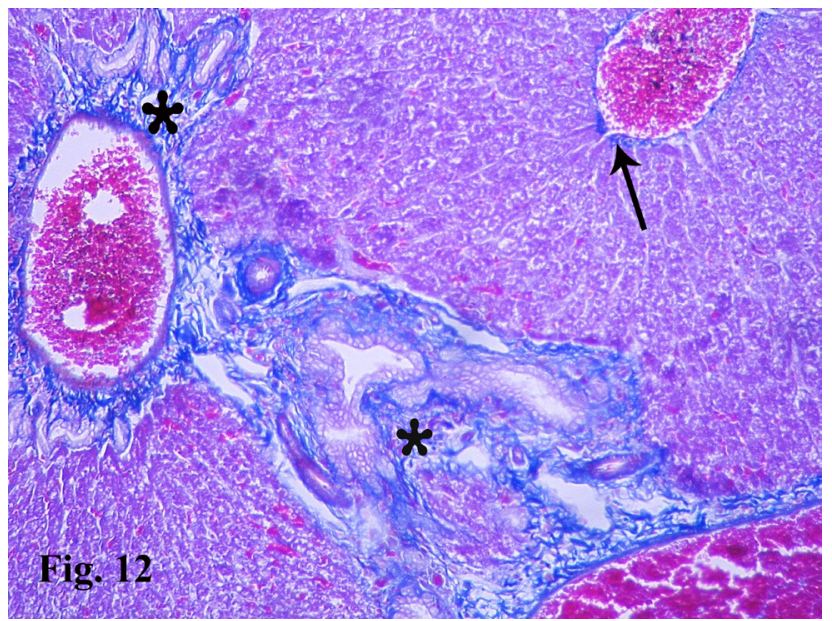

Fig. 12: showing an apparent increase in the amount of collagen fibers $(*)$ in the portal tract and around the central vein $(\uparrow)$ Group II (Mallory's triple stain X250). 


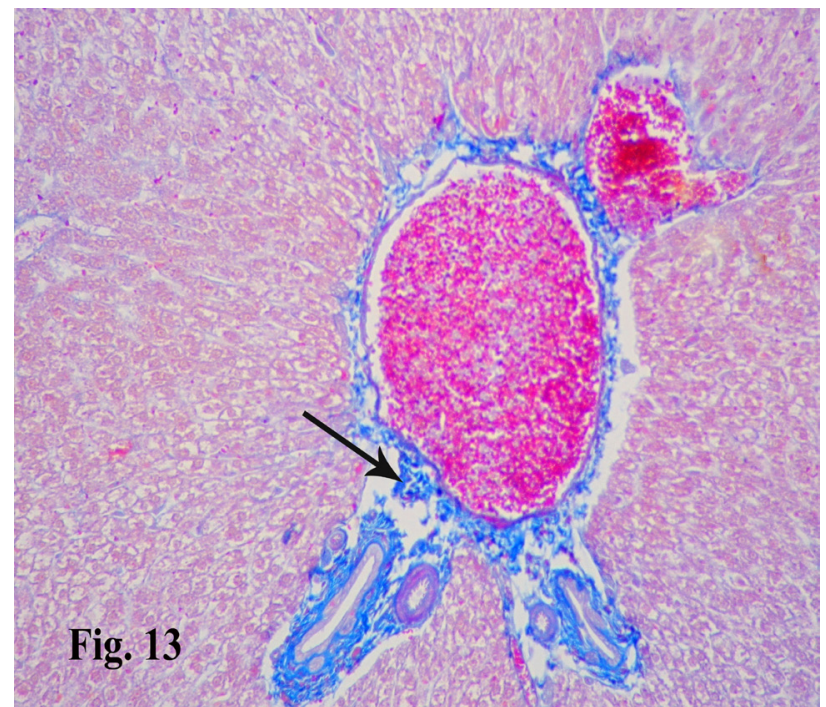

Fig. 13: showing collagen fibers $(\uparrow)$ in the portal tract. Group III (Mallory's triple stain X250).

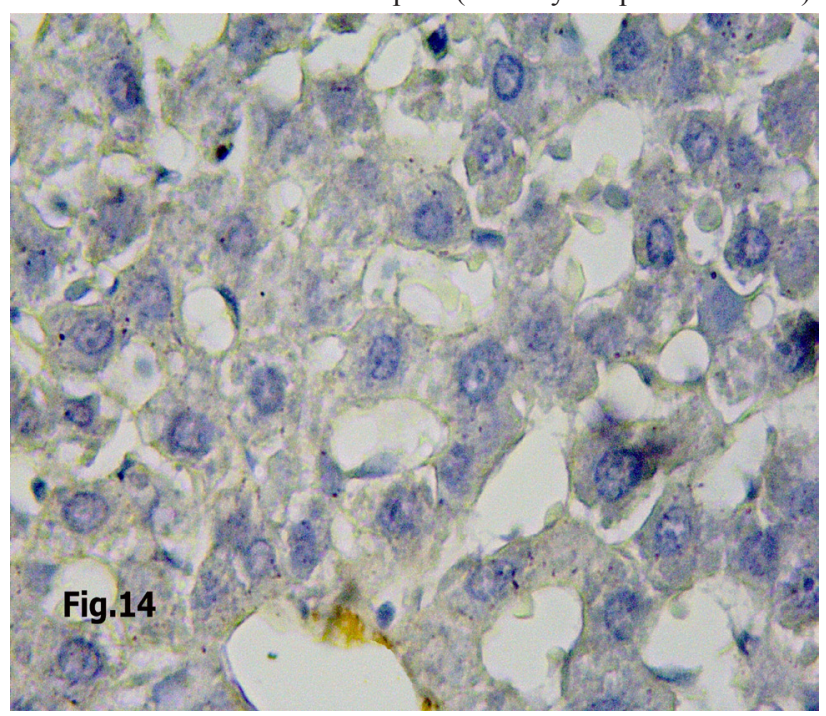

Fig. 14: showing the hepatocytes of the control group with negative TNF-a

reaction.

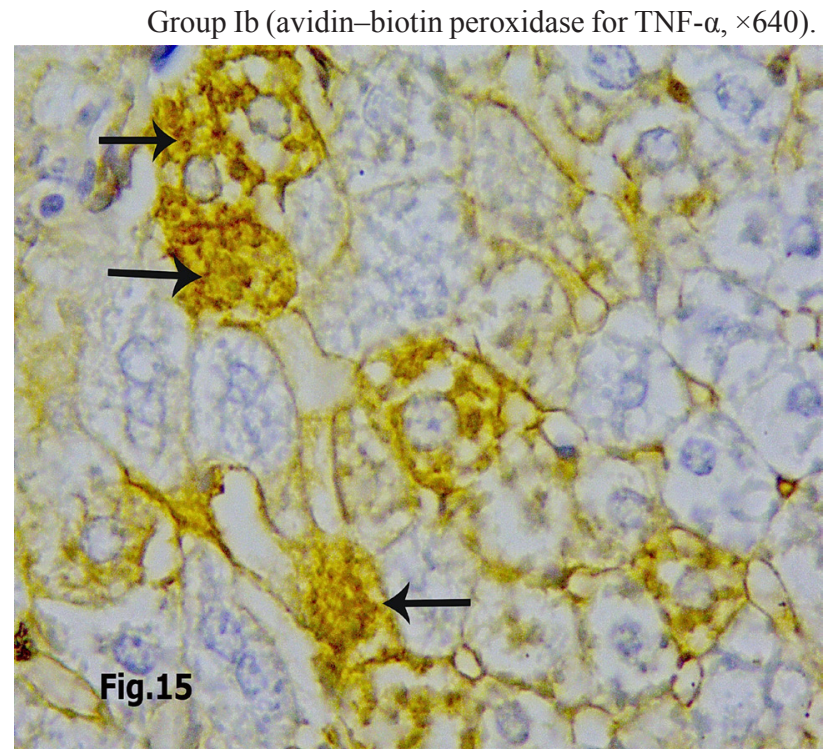

Fig. 15: showing hepatocytes with positive TNF- $\alpha$ reaction ( $\uparrow$ ) Group II (avidin-biotin peroxidase for TNF- $\alpha, \times 640$ ).

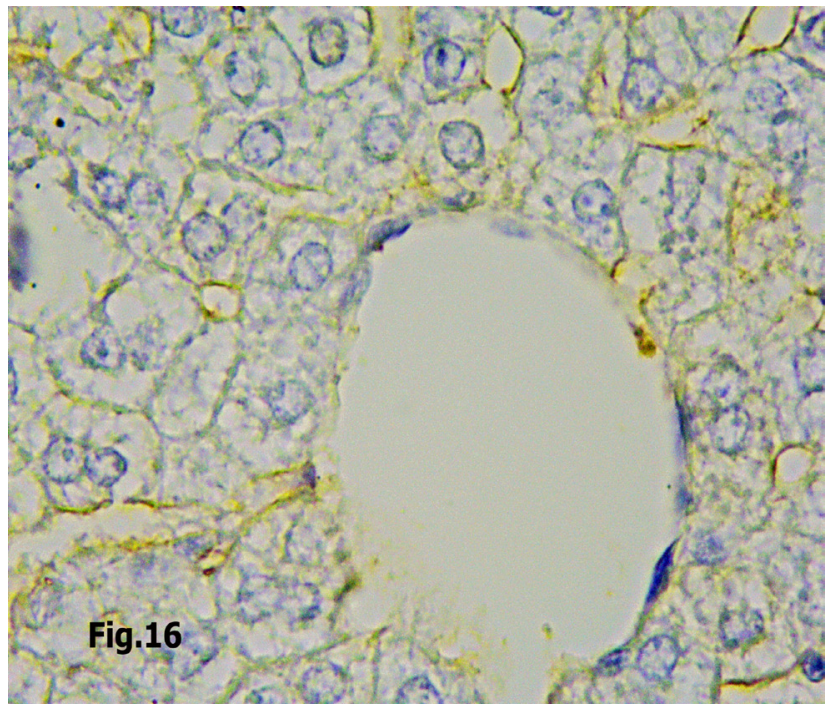

Fig. 16: showing hepatocytes with negative TNF- a reaction Group III (avidin-biotin peroxidase for TNF- $\alpha, \times 640$ ).

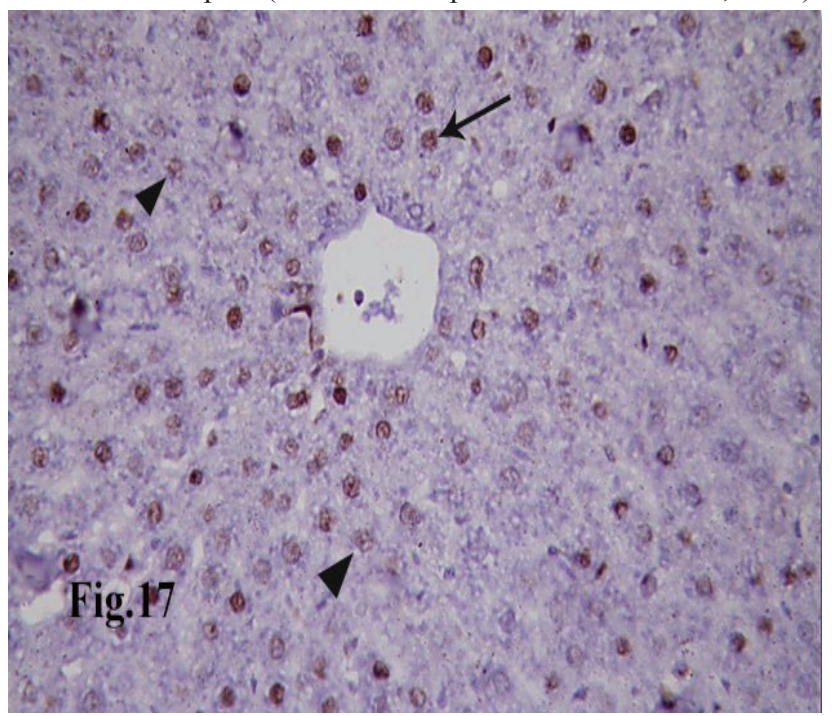

Fig. 17: showing few hepatocytes with faint PCNA positive nuclei $(\uparrow)$. Notice the negative reaction of other nuclei $(\boldsymbol{\Delta})$. Group Ia (avidin-biotin peroxidase for PCNA $\times 400$ ).

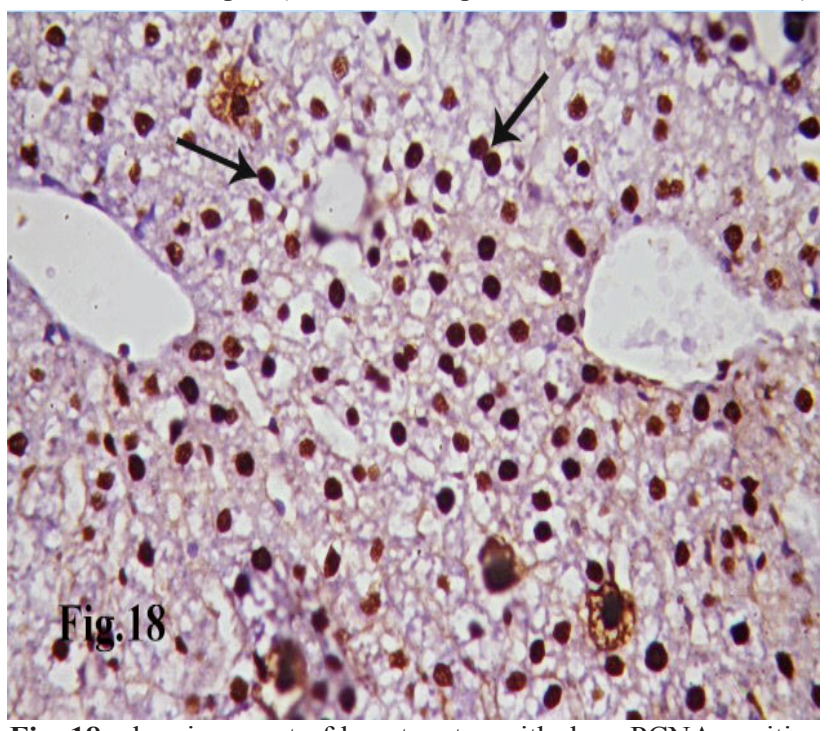

Fig. 18: showing most of hepatocytes with deep PCNA positive nuclei $(\uparrow)$. Notice the vacuolated cytoplasm in hepatocytes. Group II (avidin-biotin peroxidase for PCNA $\times 400$ ). 


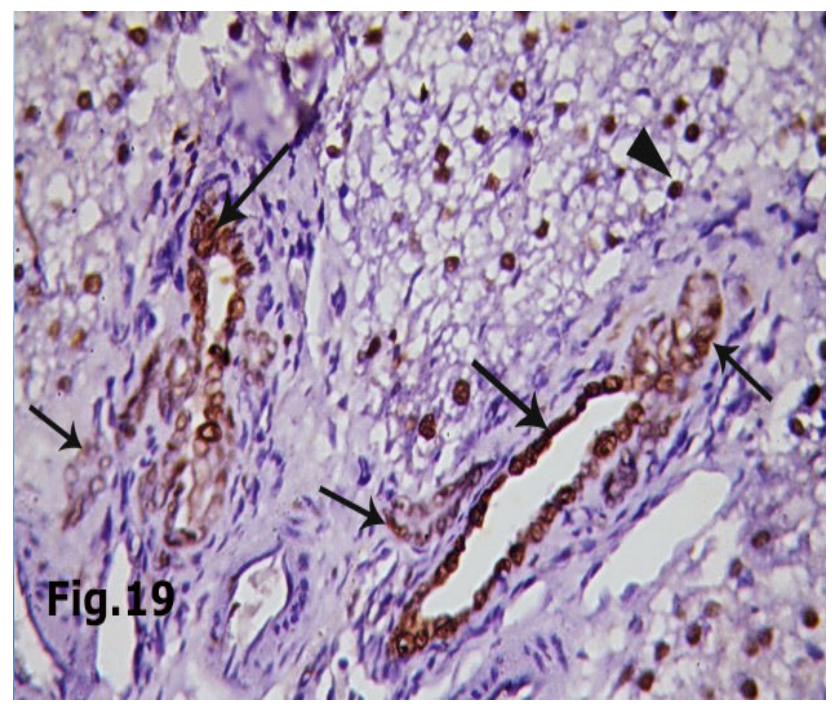

Fig. 19: showing numerous deeply PCNA positive nuclei of cells lining proliferating bile ducts at portal tracts $(\uparrow)$. Notice the deeply stained nuclei of hepatocytes $(\boldsymbol{\Lambda})$. Group II (avidin-biotin peroxidase for PCNA $\times 400$ ).

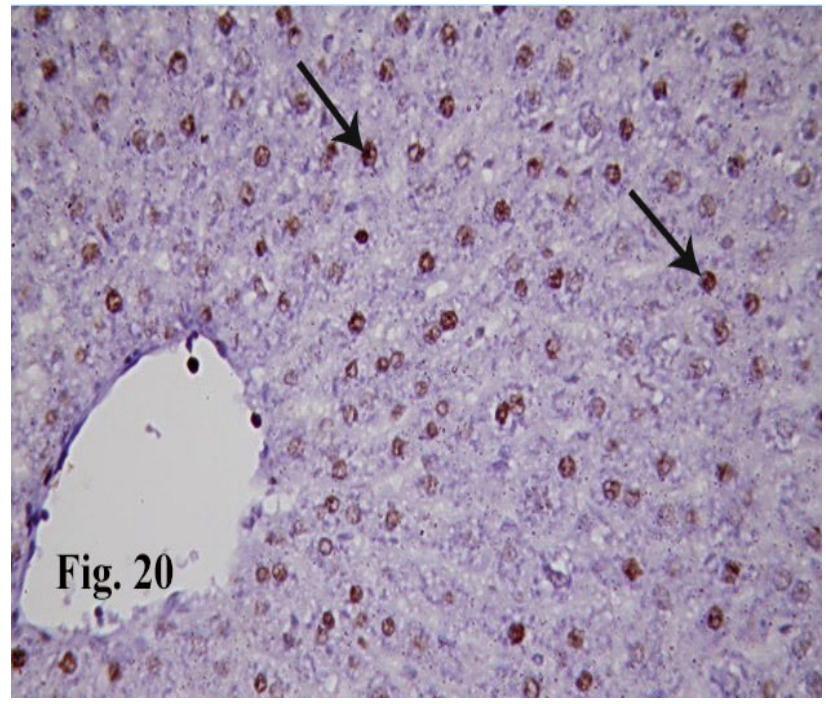

Fig. 20: showing apparent fewer hepatocytes with PCNA positive nuclei $(\uparrow)$. Group III (avidin-biotin peroxidase for PCNA, $\times 400$ ).

\section{DISCUSSION}

The central role of liver in drug metabolism predisposes it to toxic injury. For the previous reason, the liver was chosen in the present study. Carbon tetrachloride is the most widely used hepatotoxin in studying liver fibrosis and cirrhosis in rodents. It mimics human chronic disease associated with toxic damage ${ }^{[20]}$. It was also mentioned that liver necrosis induced by $\mathrm{CCL}_{4}$ is an example of a model for experimental liver necrosis caused by oxygen free radicals ${ }^{[21]}$. The only treatment of liver fibrosis currently available is liver transplantation, which is, however, hampered by high treatment costs and the limited number of liver donors. Thus, there is an urgent need for clinical strategies to manage liver fibrosis ${ }^{[20]}$.

The main advantage of using natural or dietary compounds is that they seem to have low toxicity and show very few adverse side effects. Ginger (Zingiber officinale) is widely used all over the world as a spice and condiment in daily cooking. It is a natural food component with many active phenolic compounds such as gingerol ${ }^{[22]}$.

The present work was carried out to study the possible protective role of 6 -gingerol in a model of liver injury induced by $\mathrm{CCL}_{4}$ in adult male albino rats.

In this study, the health of animals was carefully monitored. Administration of ginger was not associated with apparent weight loss or changes in general conditions. Rats treated with the $\mathrm{CCL}_{4}$ alone showed apparent decrease in body weight, suggesting that hepatotoxicity might have contributed to this loss.

In the current work, the IP injection of $\mathrm{CCL}_{4}$ in rats of group II produced severe degenerative changes in their liver. Examination of H\&E stained sections of this group showed loss of the usual hepatic architecture. Most of the liver cells were seen highly vacuolated. According to the opinion of some authors, it was suggested that these vacuoles might contain accumulated fat secondary to fatty degeneration of the liver ${ }^{[23]}$. Congestion of blood sinusoids and infiltration with inflammatory cells in the portal tract area were also seen. Similar findings were observed by other authors ${ }^{[23,24]}$. They reported that $\mathrm{CCL}_{4}$ treatments of rats produced hepatic necrosis, inflammation and fatty accumulation. Recently, it was reported that Liver from $\mathrm{CCL}_{4}$ treated rats showed moderate or severe degeneration and necrosis of hepatocytes around the central vein region, fatty changes, inflammatory cell infiltration and congestion ${ }^{[20,25]}$. It was concluded that $\mathrm{CCL}_{4}$ facilitates the generation of hepatotoxins that can result in morphologic abnormalities ${ }^{[26]}$

Proliferation of bile ducts was also noticed in the portal tract of group II. This was explained by other authors who stated that evidence from human histopathology and experimental studies with rodents showed that hepatocytes and cholangiocytes may function as "facultative stem cells" and undergo transdifferentiation, or reprogramming, from one cell type to the other to rescue failed regeneration of hepatocytes or cholangiocytes. It was found that in rats given acetylaminofluorene (which is carcinogenic and causes DNA damage) followed by $\mathrm{CCl}_{4}$, centrilobular necrosis occurs and rapidly proliferating cells appear in periportal areas, resembling cholangiocytes, with markers of biliary cells and hepatocytes. The immediate periportal hepatocytes undergo transdifferentiation directly into ductal structures lined by ductular hepatocytes, and became biliary ductules. They reported that in situations of severe hepatocyte depletion or near absolute inhibition of hepatocyte proliferation, cholangiocytes can generate hepatocytes and liver progenitor cells. They added 
that this should not be entirely surprising, as several studies from the 70 s and 80 s have shown the plasticity of the hepatic epithelial phenotypes. Hepatocytes in primary culture express biomarkers characteristic of cholangiocytes as gamma-glutamyl transpeptidase, alkaline phosphatase $\mathrm{e}^{[27]}$

It was reported that structural integrity of the sinusoids was necessary for the maintenance of normal exchanges of fluids, particles, and metabolites. Impairment of exchange is a major contributing factor of hepatic dysfunction in liver fibrosis ${ }^{[28]}$. In the present study, the hepatotoxic pathological effect of $\mathrm{CLL}_{4}$ was ameliorated with partial disappearance of hepatic damage when treatment was combined with 6-gingerol. Thus, 6-gingerol appeared to play a key role in preservation of the structural integrity of the hepatocellular structures. It was reported that ginger extracts revealed significant inhibitory properties against free radical attack and lipid peroxidation, as well as potent protective effects on hepatocytes against oxidative damage ${ }^{[28,29]}$. It was reported that daily supplement of ginger extract could increase blood levels of antioxidant enzyme, and decrease oxidative stress blood levels. This result might confirm the antioxidant pharmacological activity of ginger. No serious adverse effects were reported after taking ginger extract as a daily supplement ${ }^{[29]}$.

In the current study, periportal fibrosis was detected in Mallory stained sections after $\mathrm{CCL}_{4}$ administration. These results were confirmed by morphometric and statistical studies. The area percentage of the collagen fibers was significantly increased in the rats receiving $\mathrm{CCL}_{4}$ alone (group II) as compared to that of the control group (group I). Same findings were observed by others ${ }^{[24,30]}$ who concluded that $\mathrm{CCL}_{4}$ administration produced an extensive liver fibrosis.

It was reported that liver fibrosis is a response to various chronic liver injuries. The process leading to liver fibrosis resembles the process of wound healing, including inflammation, synthesis of collagenous and noncollagenous extracellular matrix components, and tissue remodeling. The origin of liver fibrogenesis is initiated by the damage of hepatocytes, resulting in the recruitment of inflammatory cells and platelets, and activation of Kupffer cells, with subsequent release of cytokines and growth factors ${ }^{[20,28]}$. Same explanation was previously stated by other authors, who added that these factors activate hepatic stellate cells which proliferate and transform into myofibroblasts-like cells that deposit large amounts of connective tissue components ${ }^{[20,31]}$. It was also reported that $\mathrm{CCL}_{4}$ causes oxidative stress that activates hepatic stellate cells. The activated hepatic stellate cells become the main source of most cytokines and collagen proteins ${ }^{[20,32]}$.
It was mentioned that collagen deposition has lasting consequences on hepatic patterns of blood flow and perfusion of hepatocytes ${ }^{[33]}$. The present study proved that the hepatic pathology caused by administration of $\mathrm{CLL}_{4}$ was prevented by concomitant treatment with ginger. A significant decrease in the mean area percentage of collagen deposition was noticed in coadministration of 6-gingerol and $\mathrm{CLL}_{4}$. The present study suggested 6-gingerol as a potential antifibrotic agent.

Cellular infiltration in the portal tract area was also noticed in $\mathrm{CCL}_{4}$ group. It was reported that liver inflammation leads to the secretion of proinflammatory cytokines and chemokines which, in turn, contributed to amplification of the inflammatory signal and subsequent progression of the diseases. Nuclear factor kappa $\mathrm{B}(\mathrm{NFkB})$ is the master regulator of the hepatic inflammatory response. Under basal conditions, NFkB is present in the cytoplasm of hepatocytes in a latent form. Upon exposure to proinflammatory stimuli, $\mathrm{NFkB}$ is activated and migrates to the cell nucleus where it directs transcription of target genes. Ginger has been known as a valuable medicinal herb having anti-inflammatory properties. Different studies have shown that ginger extracts suppress inflammation through inhibition of the classical NFkB pathway in various cell types and tissues ${ }^{[34]}$.

In the present study, we tested the potential anti-inflammatory effect of 6-gingerol by using an immune-histochemical technique to detect the presence of the inflammatory marker TNF- $\alpha$. We noticed that 6-gingerol significantly reduced the elevated expression of TNF- $\alpha$ in hepatocytes. This was also noticed by other authors ${ }^{[35]}$. It was reported that gingerol may act as anti-inflammatory agent by inactivating NFKB through the suppression of the pro-inflammatory TNF- $\alpha$. Ginger has long been used in traditional medicine as a cure for some diseases including inflammatory diseases. Gingerol has antioxidant, and anti-inflammatory effect ${ }^{[22,35]}$. It was reported that the protective effects of ginger against hepatotoxicity are mainly due to its antioxidant and anti-inflammatory effects. It also exhibited free radical scavenging, inhibition of lipid peroxidation and DNA protection indicating strong antioxidant properties. Previous reports documented the ability of this compound to directly inhibit prostaglandin and leukotriene synthesis. Six-gingerol, besides having various pharmacological and physiological effects including anti-inflammatory, analgesic, antipyretic and gastroprotective activities, is also reported to have anti-hepatotoxic activities ${ }^{[1]}$. The anti-inflammatory effect of ginger was identified in the current study as ginger administration significantly decreased the cellular infiltration in hepatic tissues. 
PCNA immunostaining technique was used in the present study to detect the proliferating cells. It was stated that PCNA is a labeling technique for investigating cell proliferation ${ }^{[36]}$.

In the current study, PCNA positive nuclear reaction was seen in few hepatocytes of the control rats. It was explained that the normal hepatocytes are generally quiescent and replicate in a limited and regulated manner ${ }^{[37]}$.

In the current study, in rats that received $\mathrm{CCL}_{4}$ alone, PCNA positive reaction was seen in hepatocytes surrounding the central vein and in bile ducts in the portal tracts. It was suggested that the liver cells of rats treated with $\mathrm{CCL}_{4}$ have stronger replicative activity, as reflected by the significant increase in number and area percentage of PCNA-positive cells. This was against findings of other authors who reported that the replicative activity of hepatocytes diminishes in advanced cirrhosis in humans and in chronic liver injury in mouse, reaching a state of replicative senescence ${ }^{[37]}$. This might be because the duration in the current study was less than that needed to obtain chronic cirrhosis

In the present study with pretreatment with 6-gingerol, a significant decrease in the number and area percentage of PCNA positive hepatocytes was noticed in comparison to $\mathrm{CCL}_{4}$ group. This might be explained by the opinion of other authors who reported that gingerol improved the elevated serum liver enzymes in both carbon tetrachloride and acetaminophen induced hepatotoxicity. They reported that this protective effect was also confirmed by histological examination of the liver ${ }^{[38]}$.

It was reported that ginger exhibited free radical scavenging, inhibition of lipid peroxidation, DNA protection indicating strong antioxidant properties. The protective effects of ginger against hepatotoxicity are mainly due to its antioxidant and anti-inflammatory effects. Since the mechanism of hepatic injury may be due to inflammatory process, so the hepato-protective activity of ginger may be due to its content of volatile oils, which showed anti-inflammatory, analgesic and immunomodulatory effects ${ }^{[1]}$.

\section{CONCLUSION}

The present work came to a conclusion that 6-gingerol a known compound from ginger- has a promising role in protection against hepatic injury induced by $\mathrm{CLL}_{4}$.

\section{CONFLICT OF INTEREST}

There are no conflicts of interest.

\section{ACKNOWLEDGMENT:}

Many thanks are due to Prof. Doctor Adel Zohdy and Prof. Doctor Shoheir Kamal for reviewing this paper.

\section{REFERENCES}

1. Hesami Z, Jamshidzadeh A, Ayatollahi M, Geramizadeh B, Farshad O, Vahdati A. Effect of Platelet-Rich Plasma on CCl4-Induced Chronic Liver Injury in Male Rats. Int J Hepatol. 2014; 2014:932930.

2. Atta AH, Elkoly TA, Mouneir SM, Kamel G, Alwabel NA, Zaher S. Hepatoprotective effect of methanol extracts of Zingiber officinale and Cichorium intybus. Indian J Pharm Sci. 2010 Sep; 72(5):564-70

3. Wang $\mathrm{S}, \mathrm{Xu} \mathrm{H}, \mathrm{Xu}$ J, Zhang Y, Liu Y, Deng YH, Chen D. Sustained liver targeting and improved antiproliferative effect of doxorubicin liposomes modified with galactosylated lipid and PEG-lipid. AAPS Pharm SciTech. 2010 Jun; 11(2):870-7

4. Adewole SO, Salako AA, Doherty OW, Naicker T. Effect of Melatonin on carbon tetrachloride-induced kidney injury in Wistar rats. Afr J Biomed Res 2007; 10:153-164.

5. Ozturk F, Ucar M, Ozturk IC, Vardi N, Batcioglu K. Carbon tetrachloride induced nephrotoxicity and protective effect of betaine in Sprague-Dawley rats. Urology 2003; 62:353-356.

6. He SM, Chan E, Zhou SF. ADME properties of herbal medicines in humans: evidence, challenges and strategies. Curr Pharm Des. 2011; 17(4):357-407.

7. Fogden E, Neuberger J. Alternative medicines and the liver. Liver Int. 2003 Aug; 23(4):213-20.

8. Sahebkar A. Potential efficacy of ginger as a natural supplement for nonalcoholic fatty liver disease. World J Gastroenterol 2011 January 14; 17(2): 271-272

9. Attyah AM and Ismail SH. Protective Effect of Ginger Extract Against Cisplatin-Induced Hepatotoxicity and Cardiotoxicity in Rats. Iraqi J Pharm Sci, 2012; Vol,21(1) 2012

10. Ghasemzadeh A, Jaafar HZ, Rahmat A, Wahab PE, Halim MR. Effect of Different Light Intensities on Total Phenolics and Flavonoids Synthesis and Antioxidant Activities in Young Ginger Varieties (Zingiber officinale Roscoe). Int J Mol Sci. 2010 Oct 12; 11(10):3885-97

11. Abd-ElAty OA and Morgan EN. GingerAdministration has a Protective Effect on the Liver of Albino Rats Treated with 6-Mercaptopurine. Journal of American Science, 2011;7(8) 
12. Hansson GK. Inflammation, atherosclerosis, and coronary artery disease. N Engl J Med 2005;352:168595 .

13. Wang LF, Chai CY, Kuo WR, Tai CF, Lee KW, Ho KY. Correlation between proliferating cell nuclear antigen and p53 protein expression and 5-year survival rate in nasopharyngeal carcinoma. Am J Otolaryngol. 2006;27(2):101-105.

14. Escoubas P, Lajide L, Mizutani J. Termite antifeedant activity in Aframomum activity. Phytochemistry. 1995 40:1097-1099

15. Mansour MA, Bakheet SA, Aleisa AM: Protective effect of 6-gingerol against cardiotoxicity induced by doxorubicin. Open Pharmacol J. 2008; 2:20-23

16. Zhen $\mathrm{M}-\mathrm{C}$, Wang $\mathrm{Q}$, Huang $\mathrm{X}-\mathrm{H}$, Cao L -Q, Chen X -I, Sun K. Green tea polyphenol epigallocatechin3 -gallate inhibits oxidative damage and preventive effects on carbon tetrachloride-induced hepatic fibrosis. J Nutr Biochem 2007; 18:795-805.

17. Paget GE and Barnes JM: Evaluation of drug activities. (1964) Vol. I. London Academic Press, p. 30.

18. Suvarna K, Layton C, Bancroft J. Theory and practice of histological techniques. 7th ed. USA: Churchill Livingston; 2013.

19. Goldstone LA. Understanding medical statistics. 1st ed. London: London William Mairmann Medical Books Limited; 1983.

20. Yanguas SC, Cogliati B, Willebrords J, Maes M, Colle I, Bossche BD, de Oliveira MC, Andraus W, Alves VA, Leclercq I, and Vinken M. Experimental models of liver fibrosis. Arch Toxicol. 2016 May; 90(5): $1025-1048$.

21. Uskoković-Marković S, Milenković M, Topić A, Kotur-Stevuljević J, Stefanović A and Antić-Stanković J. Protective effects of tungstophosphoric acid and sodium tungstate on chemically induced liver necrosis in Wistar rats. J Pharm Sci.: 2007, 10(3):340-9.

22. Habib SH, Makpol S, Abdul Hamid NA, Das S, Ngah WZ, Yusof YA. Gingerextract (Zingiber officinale) hasanti-cancerand anti-inflammatory effectson ethionine-induced hepatomarats. CLINICS 2008; 63(6):807-13

23. Tasci I, Mas M and Bilgin M. Ultrastructural changes in hepatocytes after taurine treatment in $\mathrm{CCl} 4$ induced liver injury World J Gastroenterol: 2008; 14(31): 4897-4902

24. Liu F, Liu Z, Wu N, Cong X, Fei R, Chen H, Wei L. Transplanted Endothelial Progenitor Cells Ameliorate Carbon Tetrachloride-Induced Liver Cirrhosis in Rats. Liver Transplantation: 2009; 15:1092-1100.
25. Lee I, Kim S, Baek H, Moon C, Kang S, Kim S, Kim Y, Shin I and Kim J. The involvement of Nrf2 in the protective effects of diallyl disulfide on carbon tetrachloride-induced hepatic oxidative damage and inflammatory response in rats. Food Chem Toxicol: $2014 ; 63: 174-85$.

26. Ijiri Y, Kato R, Sadamatsu M, Takano M, Okada Y, Tanaka $\mathrm{K}$ and Hayashi T. Chronological changes in circulating levels of soluble tumor necrosis factor receptors 1 and 2 in rats with carbon tetrachlorideinduced liver injury. Toxicology: pii: 2014; S0300483X(13)00336-3

27. Michalopoulos GK and Khan Z. Liver stem cells: Experimental findings and implications for human liver disease. Gastroenterology. 2015 Oct; 149(4): 876-882.

28. Ahmed MAAS. The Protective Effect of Ginger (Zingiber Officinale) Against Adriamycin- Induced Hepatotoxicity in Rats: Histological Study. Life Science Journal; 2013,10 (1)

29. Danwilai K, Konmun J, Sripanidkulchai B and Subongkot S. Antioxidant activity of ginger extract as a daily supplement in cancer patients receiving adjuvant chemotherapy: a pilot study. Cancer Manag Res. 2017; 9: 11-18

30. Hardjo M, Miyazaki M, Sakaguchi M, Masaka T, Ibrahim S, Kataoka K and Huh N. Suppression of carbon tetrachloride-induced liver fibrosis by transplantation of a clonal mesenchymal stem cell line derived from rat bone. Cell transplantation: 2009; 18(1):89-99.

31. Bauer $M$ and Schuppan D. TGFbeta1 in liver fibrosis: time to change paradigms? FEBS: 2001; 27: 502(1-2):1-3.

32. Yang F, Fang B and Lou J. Effects of Haobie Yangyin Ruanjian Decoction on hepatic fibrosis induced by carbon tetrachloride in rats. World J Gastroenterol: 2010; 16(12): 1458-64

33. Kumar V, Cotran RS and Robbins SL. Basic Pathology 7th ed.The Curtis Center. Independence Square West. Philadelphia, PA., 2003; 19106: 593

34. Li XH, McGrath KC, Tran VH, Li YM, Duke CC, Roufogalis BD, Heather AK. Attenuation of Proinflammatory Responses by $\mathrm{S}$ [6]-Gingerol via Inhibition of ROS/NF-Kappa B/COX2 Activation in HuH7 Cells. Evid Based Complement Alternat Med. 2013; 2013:146142

35. Tzeng TF, Liou SS, Chang CJ and Liu IM. 6-Gingerol Protects against Nutritional Steatohepatitis by Regulating Key Genes Related to Inflammation and Lipid Metabolism. Nutrients 2015, 7, 999-1020. 
36. Foley F, Dietrich D, Swenberg J and Maronpot R. Detection and Evaluation of Proliferating Cell Nuclear Antigen (PCNA) in Rat Tissue by an Improved Immunohistochemical Procedure. Journal of histotechnocology: 1991; 14 (4): 237-241.

37. Cheung P, Zhang Q, Zhang Y, Bai Y, Lin G, Chan M, Fong B, Shi C, Shi L, Chun Y, Hsiang-Fu J. Effect of WeiJia on carbon tetrachloride induced chronic liver injury. World journal of gastroenterology (WJG): 2006; 12 (12): 1912-7.

38. Yemitan OK and Izegbu MC. Protective effects of Zingiber officinale (Zingiberaceae) against carbon tetrachloride and acetaminophen-induced hepatotoxicity in rats. Phytother. Res., 2006; 20(11): 997-1002. 


\section{الملخص العربى}

الاور الوقائي المحتمل لله-جينجيرول على نموذج للضرر الكبدي الناجم عن استخدام رابع

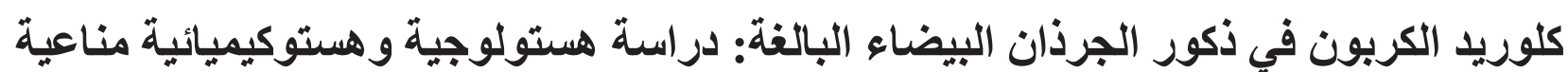

\section{هاني كمال، غادة جلال حمام ، داليا علاء}

\section{قسم الهستولوجيا وبيولوجيا الخلية. كلية الطب - جامعة عين شمس- القاهرة}

المقدمة: يعد رابع كلوريد الكربون من المواد البيئية القوية ذات التأثير السمي على الكبد والتي كانت تستخدم بكثرة سابقا في التطبيقات الصناعية. كما يعتبر 7-جينجيرول العنصر النشط الرئيسي في الزنجبيل، وهو المسؤول عن العديد من الخصائص

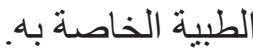
الهدف من البحث: تقييم الدور التحصيني المحتمل للآ- جينجيرول على نموذج للضرر الكبدي الناجم عن استخدام رابع كلوريد الكربون في ذكور الجرذان البيضاء البالغة. المواد وطرق البحث: استخدم في هذه الدراسة ثلاثون من ذكور الجرذان البيضاء البالغة وتم تقسيمهم إلى ثلاث مجموعات. المجموعة الأولى: المجموعة الضابطة و التي قسمت إلى ثلاث مجموعات فرعية. المجموعة الثانية: تم حقها داخل البريتون بر ابع كلوريد الكربون مرتين/الأسبوع ولمدة أسبو عين. المجموعة الثالثة: تم اعطاؤها 7-جينجرول عن طريق الفم يوميا خمسة أيام قبل حقن رابع كلوريد الكربون وحتى نهاية التجربة. تمت التضحية بجميع الجرذان بعد أسبو عين من أخر حقنة لر ابع كلوريد الكربون. تم تجميع الفص الأيمن للكبد من جميع الجرذان وتمت معالجته. تم عمل مقاطع هستولوجية لصبغة الهيماتوكسلين و الايوسين, المالوري, و تحليل مناعي لكل من عامل نخر الورم ألفا وال PCNA. كما تم إجر اء تحليل إحصائي للنتائج. النتائج: أظهرفحص عينات الكبد في المجموعة الثانية وجود فجوات في سيتوبلازم خلايا الكبد واحتقان في الجيوب الدموية الكبدية. كما لوحظ أيضا احتقان في فرع الوريد البابي و اتساع في القنوات الصفراوية و زيادة في الياف الكو لاجين في المسلك البابي. كما لوحظت أيضا زيادة كثافة رد الفعل المناعي الإيجابي لكل من عامل نخر الورم ألفاو ال PCNA. أظهر فحص الكبد في المجمو عة الثالثة صورة مقاربة لما هو عليه للمجموعة الضابطة. وأكدت نتائج التحليل الإحصائي ماظهر في النتائج الهنتولوجية. الاستنتاج: اكدت هذه الدراسة أن المعالجة المسبقة باستخدام آ- جينجيرول يمكن أن تمنع الضرر الكبدي الناجم عن استخدام رابع كلوريد الكربون. 